\title{
DETERMINANTS OF OFF-BALANCE SHEET (OBS) ACTIVITIES: A CASE OF SELECTED RETAIL BANKS IN MALAYSIA
}

\author{
Oladokun Nafiu Olaniyi ${ }^{1}$, Shamsul Kamariah Abdullah ${ }^{2}$ \\ and Charmele Ayadurai ${ }^{3}$ \\ ${ }^{1}$ Curtin University Malaysia \\ E-mail:nafiuo@gmail.com/nafiuo@curtin.edu.my \\ ${ }^{2}$ Curtin University Malaysia \\ E-mail: Shamsul.a@curtin.edu.my \\ ${ }^{3}$ E-mail: c.ayadurai@edu.salford.ac.uk
}

\begin{abstract}
The present paper examines factors influencing the Off-Balance Sheet activities of selected commercial banks in Malaysia for the period 20042014. OBS activities are an integral part of financial institutions in response to the needs of businesses for different types of guarantee that have conflicting implications on the stability of financial institutions. Data collected on selected banks from the Bankscope database was analyzed using the Generalized Method of Moments (GMM) regression. Specifically, the study built its analysis on three main recognized determining factors namely: (1) liquidity motives, (2) credit risk transfer motive, (3) profitability motives, and (4) capital arbitrage motive. The findings thus suggest that the selected banks mainly used OBS instruments for capital arbitrage purpose, enhancing operational efficiency and managing loan portfolio risks. The findings further suggested that its usage for capital arbitrage purposes may undermine the regulatory measures of accurately estimating and monitoring the risk of banks. The findings thus offer significant practical and policy implications that can help to enhance financial stability.
\end{abstract}

Keywords: off-balance sheet, liquidity, credit risk transfer, profitability, capital arbitrage

\section{ARTICLE INFO}

Article History:

Received: 30 November 2018

Accepted: 21 March 2019

Published: 30 April 2019 


\section{INTRODUCTION}

Following the outbreak of the worst financial crisis for more than 80 years, the attention of regulators, academics and other stakeholders in the financial sector is directed to new activities of commercial banks such as the OffBalance Sheet Activities (OBS).

The OBS can be described as a contingent commitment or contract which generates income for the banks but does not directly reflect under the assets or liabilities section in the balance sheet (Nachane \& Ghosh, 2002). The occurrence of the contingent liabilities that arises from such activities thus imposes equivalent risks on the balance sheet of financial institutions. The OBS activities of commercial banks includes: guarantee such as commitments, standby letters of credit, spot foreign exchange contract, interest rate contract and derivatives contracts. A majority of the OBS instruments (e.g. interest rate swap, forward and future contract, option contract and securitization) were mainly developed to address the growing risks generated from the activities of the financial institutions in a deregulated environment and fee generation purposes.

The dramatic changes in the landscape of financial institutions over the past few decades have altered the landscape of financial institutions. The emergence of innovative activities particularly the OBS offers opportunities for financial institutions to diversify from the traditional intermediation method to fee based activities. The growth in the OBS which has come in response to the need of businesses and other customers has shown to have a conflicting impact on the stability and soundness of financial institutions.

OBS activities are a double edged sword that is capable of bringing both favorable and unfavorable consequences to the financial system and the economy as a whole. Banks are induced to use the OBS for a variety of reasons. This includes enlarging debt capacity without appearing on the balance sheet, managing liquidity, improvement of credit rating, capital arbitrage and tax reduction.

Banks in Malaysia just like other emerging countries have been actively involved in OBS activities for over two decades (Karim \& Gee, 2007). As indicated in Table 1 below, the commitments and contingencies 
transaction by the commercial banks in Malaysia increased from about RM1.8 billion to RM2.5 billion between 2012 and 2016. Table 2 which presents the estimated OBS transaction in relation to the total assets and loans of the banks indicated that the total amount of OBS transactions exceed the total assets of the banks while trailing behind the total loans generated by the banks. All these activities show an increased usage of OBS activities in the Malaysian banking system.

Table 1: Commercial Banks: Commitments and Contingencies

\begin{tabular}{lccccl}
\hline \multicolumn{7}{c}{ As at end } \\
\hline \multicolumn{7}{c}{ Million } \\
\hline $\begin{array}{l}\text { Assets sold with recourse and } \\
\text { commitments with drawdown }\end{array}$ & $\mathbf{2 0 1 2}$ & $\mathbf{2 0 1 4}$ & $\mathbf{2 0 1 5}$ & $\mathbf{2 0 1 6}$ \\
\hline Credit extension commitments & $444,293.6$ & $470,299.8$ & $472,472.5$ & $490,961.9$ & $503,193.1$ \\
\hline Direct credit substitutes & $24,960.5$ & $33,087.9$ & $29,897.3$ & $32,830.2$ & $30,867.5$ \\
\hline $\begin{array}{l}\text { Foreign exchange-related } \\
\text { contracts }\end{array}$ & $518,150.2$ & $577,388.4$ & $760,062.7$ & $891,122.5$ & $924,253.8$ \\
\hline Interest rate-related contracts & $716,494.7$ & $772,958.0$ & $791,736.1$ & $858,058.7$ & $941,300.7$ \\
\hline Trade-related contingencies & $10,644.2$ & $10,677.4$ & $13,724.3$ & $13,505.9$ & $11,834.1$ \\
\hline Transaction-related contingencies & $45,928.8$ & $50,561.5$ & $57,964.8$ & $60,492.9$ & $66,338.3$ \\
\hline Underwriting obligations & 445.0 & 522.0 & 466.0 & 76.0 & 76.0 \\
\hline Others & $72,179.0$ & $55,541.2$ & $63,046.9$ & $58,523.2$ & $58,783.8$ \\
\hline Total & $1,839,149.5$ & $1,976,320.9$ & $2,196,133.0$ & $2,414,423.9$ & $2,548,714.0$ \\
\hline
\end{tabular}

Source: BNM (2016). Financial Stability and Payment Systems Report 2016 http://www.bnm.gov.my/files/publication/fsps/en/2016/zcp07_table_A.07.pdf

Table 2: Summary of Banks' Assets and Liabilities

\begin{tabular}{lcccccccc}
\hline & $\mathbf{2 0 0 7}$ & $\mathbf{2 0 0 8}$ & $\mathbf{2 0 0 9}$ & $\mathbf{2 0 1 0}$ & $\mathbf{2 0 1 1}$ & $\mathbf{2 0 1 2}$ & $\mathbf{2 0 1 3}$ & $\mathbf{2 0 1 4}$ \\
\hline \multicolumn{7}{c}{ Million Ringgit } \\
\hline Assets & $861,784.9$ & $973,358.3$ & $1,077,589$ & $1,153,482$ & $1,300,764$ & $2,102,618.1$ & $2,300,647.5$ & $2,547,970$ \\
\hline Loans & $611,895.9$ & $718,727.3$ & 802,078 & $906,731.6$ & $1,079,978$ & $1,585,841$ & $3,276,611.4$ & $4,000,138.17$ \\
\hline OBS & $469,981.9$ & $563,175.7$ & $491,482.7$ & 446,642 & $483,377.1$ & $1,951,036$ & $3,444,519$ & $3,349,855$ \\
\hline
\end{tabular}

Source: BNM (2016). Financial Stability and Payment Systems Report 2016 http://www.bnm.gov.my/files/publication/fsps/en/2016/zcp07_table_A.07.pdf

With the rapid growth of OBS activities in the 1980s and the emergence of the catastrophic global financial crisis in 2007/2008, stakeholders are keen to understand the motives for its usage and its effect on financial systems. Most of the studies in this area focus on the case of developed countries (Cooper, 2011; Kashian \& Tao, 2014; Shyu \& Reichert, 2015). Based on the extant literature, limited studies exist for the case of developing countries like Malaysia that equally experienced significant surge in OBS 
activities. The present study is thus aimed at filling this gap by exploring the determining factors for banks engagement in OBS instruments and its implications for the case of Malaysia.

Banks and other financial institutions use OBS transactions as a vehicle to move some specific assets from their balance sheet by selling expected cash flow such as mortgage and credit cards. Repackaging and selling of these assets thus serve as important source of capital for financial institutions. Meanwhile, the OBS and selling of loans provide incentives for banks to originate more loans with less regard for risks. This was the case during the 2007/2008 financial crisis.

Most of the studies on the OBS focus on financial institutions in the USA and few Europeans countries. However, a lot of emerging countries like Malaysia similarly see a surge in these activities, yet this phenomenon is not adequately studied or understood. The present study therefore explored factors influencing the OBS activities among major banks in Malaysia. Following Bannier and Hansel (2008), the present study explored the influencing factors based on the four major motives identified namely: (1) liquidity motive, (2) credit risk transfer motives, (3) capital arbitrage motives and (4) profitability motive.

The motive behind the usage of the OBS activities play an important role in the stability of financial institutions. This is because, risks associated with various motives have different associated risks. This study could therefore be useful to shareholders and stakeholders in the banking sector. By establishing the determining factors, bank regulators and management can gain further insights into the issues. More so, the contribution of the present study to the literature of the OBS area can serve as a reference for further studies in this area.

\section{LITERATURE REVIEW}

\section{Off-Balance-Sheet Activities (OBS)}

In the last two decades, activities in the banks worldwide has shifted dramatically from traditional on balance sheet activities to non-traditional 
off-balance sheet (OBS) activities (Lozano-Vivas \& Pasiouras, 2010 cited in Huo, Wang \& Li, 2015). OBS activities, such as loan commitments, securitization, standby letters of credit, and derivative securities, have expanded rapidly and have resulted in a substantial rise in the share of feebased and other noninterest income to total income (Huo, Wang \& Li, 2015).

The landscape of the financial sector in Malaysia has moved in line with the advance in technology. The sector plays an important role in facilitating the economic transformation and growth of the Malaysian economy through the various phases of economic development. Throughout Malaysia's development for the past 50 years, the economy has proven its ability and flexibility to continually keep abreast with the trend and competition in the management of its financial system. Following the Financial Sector Master-plan (FSMP) introduced in 2001, the domestic financial institutions in Malaysia underwent major restructuring, consolidation and rationalisation (Financial Sector Blueprint (FSB) 2011-2020, Central Bank of Malaysia, 2011). The rapid changes in the global economic and financial environment resulted in a more integrated and globalized environment, greater regionalization, more sophisticated and diverse investment and financing needs of the domestic economy. Malaysia thus requires a financial system that is more progressive and dynamic to advance the nation's vision towards the attainment of a high value-added, high-income economy (BNM, 2011). One of the key drivers of firms' competitive advantages and overall economic growth is technological innovation (King \& Levine, 1993; Kogan et al., 2016 cited in Duo \& Xu, 2017). In the new era of financial institutions, off-balance sheet (OBS) activities have played a greater role in the banking business following rapid technological advancement, competition and some regulatory development (Arisyi et al., 2015).

Following the adverse effect of the OBS activities otherwise called shadow banking in the global capital market, researchers, policies makers and other stakeholders are keen to unravel the motive behind its adoption and its consequences on financial institutions.

\section{Determinants of Off-Balance Sheet (OBS)}

Beginning with the liquidity motive, there are mixed arguments regarding the influence of liquidity on banks' engagement in OBS activities. 
Based on the heterogeneity nature of the OBS instruments, the effect on the liquidity of the banks depends on the feature of the OBS instruments involved. In the case of securitization for instance, Cardone-Riportella et al. (2010); Calomiris and Mason (2004); Cabiles (2011) indicated that the liquidity motive is a major factor for banks engagement in securitization. Their argument hinges on the fact that vital capital is generated by selling certain assets taking-off from the balance sheet through a special purpose vehicle. In addition, Cooper (2011) indicated that the liquidity motive is one of the aims for banks' OBS activities in order to generate more loans. In contrast, findings from the literature also reveal a negative relationship between liquidity and the OBS activities. Kashian and Tao (2014) indicated that loan commitment which is an aspect of the OBS exerts pressure on banks liquidity. The need for banks to carry out its obligation under the loan commitment contract may exert unprecedented pressure on the liquidity of financial institutions. Nachane and Saibal (2007) further revealed that the OBS does not necessarily increase liquidity of the banks. Based on the various findings, it can be perceived that the nature of the OBS instruments significantly determines its effect on bank liquidity.

Risk transfer motive of the OBS activities has been highly contended by scholars. Most of the pre-crisis studies (Brewer et al., 1996; Lynge \& Lee, 1987; Hassan, 1992) reveal that banks mainly engage in the OBS activities to improve their performance in terms of earning capability rather than a risk transfer purpose. This claim has however been debunked by the majority in the post-crisis period. Affinito and Tagliaferri (2010) in their study revealed that OBS activities provide opportunities for banks to originate more loans with less incentives to monitor those loans. The opportunity availed by the OBS to transfer the inherent risk of their loans portfolio to others perhaps contributes to less incentives to monitor the originated loans. In support of this argument, Ghosh and Nachane (2009) stated that through OBS activities, banks have the opportunity to allocate the inherent risks in their portfolio to others in the financial market. Similarly, Khasawneh and Hassan (2009) found a positive relationship between net-charge-off and OBS which suggests that banks with high bad loans tend to engage more in the OBS activities for the case of commercial banks in MENA in order to hedge the resultant risk on their loans portfolio. The global financial crisis of 2007 undoubtedly exposed the risky nature of the OBS activities and the subsequent attention that follow it from the academia, regulators 
and policy makers. Several empirical studies equally support this argument even with the pre-crisis data. Yong et al. (2007) for example empirically revealed the close relationship between OBS activities and banks' long term interest risk exposure. Through OBS activities, banks have the incentives to under-estimate the risk of their loan portfolio that has the potential to amplify their long term risks.

Due to the incentive of risk transfer through the OBS activities, most studies argued that the OBS activities significantly contribute to the risks of banks. In their study, Haq and Heaney (2012), found that the OBS activities are the major factor that positively contribute to the various bank risk measures. The study emphasized on the policy implications which suggests that the inclusion of OBS activities in banks' reports will help improve transparency in their activities. On a similar note, Calmès and Théoret (2009) revealed that OBS activities help to increase the volatility of bank's net operating revenue growth.

Through the OBS activities, studies have shown how banks exploit the gap in regulatory requirement to under-estimated their risks required for regulatory capital purposes (Ghosh \& Nachane, 2002; Elian, 2012; Shyu \& Reichert, 2015). According to the findings of those studies, banks with a high capital ratio tend to have less incentives to engage in the OBS activities. Similarly, Pereira et al. (2014) argue that the OBS activities insulate the bank loan supply which consequently weakens the effect of monetary transmission through the banks' lending channel. Banks tend to explore the opportunities available to them through the OBS activities to insulate their loan supply from monetary policy shocks. It is further revealed that the buffering effect of the OBS activity on monetary transmission is substantial, particularly for small, highly-liquid and well-capitalized banks with large OBS exposures. This thus suggests that banks engage in OBS activities to reduce the regulatory burden that emanates from regulatory capital requirement. This is in line with the argument of the regulatory capital arbitrage theory which states that banks take advantage of assets mismatch in order to reduce the required regulatory capital. Since required regulatory capital is based on the classification of assets into limited number of risk baskets which resulted in assets with different actual or economic risk to have the same capital charge (Hochberge, 2009). 
It is further revealed that the buffering effect of the OBS activity on monetary transmission is substantial, particularly for small, highly-liquid and well-capitalized banks with large OBS exposures. This thus suggests that banks engage in OBS activities to reduce the regulatory burden that emanates from regulatory capital requirements. This is in line with the argument of the regulatory capital arbitrage theory which states that banks take advantage of assets mismatch in order to reduce the required regulatory capital. Since the required regulatory capital is based on the classification of assets into a limited number of risk baskets which resulted in assets with different actual or economic risks to have the same capital charge (Hochberge, 2009).

Another factor that plays an important role in the decision to engage in the OBS activities is the profitability motive. The changing landscape of the financial institutions is due to factors such as competition, deregulation and technology advancement which have undoubtedly affected banks' revenue generation. One of the ways to mitigate the effect of these changes is to diversify into innovative products of which the OBS is a major component. In an attempt to explore the determining factors for banks engagement in the OBS activities for the case of the GCC, Elian (2012) found a negative relationship between profitability and the OBS activities. In the case of Islamic banks, Khasawneh and Al-Khadash (2014) indicated that the OBS activities help to reduce risks as well as improve the profit generated by the MENA banks. The results also indicated that the effect of the OBS activities on banks profitability is higher in banks located in oil producing countries. This thus suggests that the need to enhance banks profitability is one of the motivating factors.

On a similar note, Cooper (2011) found that Board characteristics do influence the usage of the OBS activities. Due to the available incentives, some CEOs for instance, tend to increase the OBS transaction in order to meet certain profit goals to enhance their bonus. This argument is supported by Calmes and Liu (2009) who indicated that the OBS activities significantly contribute to the operating income growth of Canadian banks.

In addition to the four factors discussed above, other bank specific factors also play an important role in the decision to use the OBS activities. One such factor is the volume of loans originated by banks which are found 
to be one of the significant influencing factors. Elian (2012). Khasawneh and Hassan (2010) found a positive relationship between the loans variable and the OBS activities for the case of the Middle East and North African (MENA) countries. This suggests that the larger the loan portfolio of the banks, the more they are likely to increase the usage of the OBS activities which serve as an instrument to mitigate or offset some of the inherent risks of their loans portfolio. A similar finding has been revealed by Ziadeh-Mikati (2014) for the case of commercial banks in the USA. In addition, economic conditions also affect the decision towards using the OBS activities. GDP is mostly used to account for economic factors. In the case of the effect of macroeconomic factors, Khasawneh and Hassan (2009); Elian (2012) found a positive relationship between GDP and OBS activities for the case of the GCC which means that that OBS activities usage tends to increase during the period of economic growth and seems to follow the business cycle. Financial institutions are expected to originate more loans during the boom period of the economy and they tend to use more OBS activities to manage the risks on those loans.

\section{DATA AND METHODOLOGY}

\section{Sample and Data}

The sample of the present study comprised of all commercial banks in Malaysia. The reason for choosing banks is due to the fact that banks are the most active users of the OBS. Data was derived from the Bankscope database covering the period from 2007-2014. The selected banks were carefully screened to ensure that all the variables needed were available and met the required criteria. Accordingly, those banks with incomplete information were dropped. The final sample comprised a total sample of 28 commercial banks comprising 9 local banks, 11 foreign banks and 8 Islamic banks.

Based on Bannier and Hansel (2007), the determinant variables were classified based on the following identified factors that play an important role in the decision to engage in the OBS activities: (1) Liquidity motive (2) risk transfer motive (3) capital motive and (4) profitability motive. In addition, we included some control variables that represented bank specific 
and macroeconomic effects. The data for the empirical analysis was obtained from the unconsolidated income statement and balance sheet data of the respective banks which were sourced from the Bankscope database of Bureau Van Dijk. Below is the table that explains the variables and their classification. The macro-economic variables were obtained from the World Development Index (WDI) database.

Table 3: Description of Variables

\begin{tabular}{|c|c|c|c|}
\hline Explanatory Variable & Notation & Classification & $\begin{array}{l}\text { Expected } \\
\text { signs }\end{array}$ \\
\hline $\begin{array}{l}\text { Natural Log of Total } \\
\text { Assets }\end{array}$ & Ln TA & Size variable & $(-/+)$ \\
\hline $\begin{array}{l}\text { Ratio of impaired loans } \\
\text { to equity }\end{array}$ & Imp Loans / Equity & Risk transfer & $(+)$ \\
\hline $\begin{array}{l}\text { Ratio of total liquid } \\
\text { assets to total deposits } \\
\text { \& borrowing }\end{array}$ & $\begin{array}{l}\text { LqdAssts/Tot } \\
\text { Dep\&Bor }\end{array}$ & Funding Variable & $(-)$ \\
\hline Cost-to-Income ratio & CIR & Performance variable & $(-/+)$ \\
\hline Total Capital Ratio & TCR & Capital Regulation & $(-)$ \\
\hline Return on Assets & ROA & Performance variable & $(-/+)$ \\
\hline Natural Log of Loans & Ln Loans & $\begin{array}{c}\text { General } \\
\text { characteristics }\end{array}$ & $(+)$ \\
\hline $\begin{array}{l}\text { Gross Domestic } \\
\text { Products }\end{array}$ & GDP & $\begin{array}{c}\text { Macroeconomic } \\
\text { variables }\end{array}$ & $(-)$ \\
\hline
\end{tabular}

\section{Methodology}

In line with Ainito and Tagliaferri (2010); Cerrato et al. (2012); Bannier and Hansel (2007). Elian (2012), Ghosh and Nachane (2002), the model for the determinants of the OBS activities in the present study was developed based on four main motivating factors namely: (1) funding, (2) risk transfer (3) profit, and (4) capital arbitrage. The general model specification for the present study is therefore presented as follows:

$$
\mathrm{Y}_{\mathrm{it}}=\alpha+\mathrm{yY}_{\mathrm{it}-1}+\beta \mathrm{X}_{\mathrm{it}}+\varepsilon_{\mathrm{it}}
$$

Where:

$$
\varepsilon_{\text {it }=\text { Vit }+ \text { Uit }}
$$


$\mathbf{Y}_{\text {it : }}$ represents off-balance sheet variable of bank $i$ at time $t$,

X: represents the independent variables including the bank specific and macroeconomic variables (Natural log of assets, ratio of impaired loans to equity, cost-to-income ratio, ratio of liquid assets to total deposit, total capital ratio, ROA, natural log of loans and GDP),

$\boldsymbol{y}$ and $\boldsymbol{\beta}$ : are the slopes parameters.

In line with Goddard et al, (2004), Nasserinia et al. (2014), the lagged dependent variable is included to account for some of the effects of previous OBS activities that might contribute to its usage. The above model thus serves as the baseline specification to assess the determinant of the OBS activities.

\section{Model Estimation}

Following Ibrahim and Law (2013), Cerrato et al. (2012), Affinito and Tagliaferri (2010), the Generalized Method of Moments (GMM) was chosen as the estimation model in this study. According to Drukker et al. (2013), the GMM is a general framework for deriving estimators. One of the main conditions for applying the GMM is that the number of cross-sectional units must be greater than the time period. Application of a standard panel model such as the OLS regression model, fixed effect panel model and random effect model are not suitable for data that are dynamic in nature and might lead to bias estimation (Ibrahim \& Law, 2012). Those models lack the ability to handle specific issues associated with panel data such as firm specific effects and potential endogeneity of the explanatory variables (Hansen et al., 1996). One of the reasons for the popularity of the GMM is its ability to handle those problems. The GMM approach on panel data has been found to be an efficient method compared to other methods (Judson $\&$ Owen, 1996). We thus used the following estimation model to estimate the determinant of OBS:

$$
\begin{aligned}
& \text { Ln OBS }=\alpha+y \ln \text { OBS }_{\text {it-1 }}+\beta_{1} \text { Ln TA }_{\text {it }}+\beta_{2} \text { Imp Loans_Equity } \\
& \text { it } \\
& \text { CIR }_{\text {it }+} \beta_{4} \text { LqdAssts_TotDep\&Bor }_{3}+\beta_{5} \text { TCR }_{\text {it }}+\beta_{6} \text { ROA }_{\text {it }}+\beta_{7} \text { Ln Loans }_{\text {it }}+ \\
& \beta_{8} \text { GDP }_{\text {it }}+\varepsilon_{\text {it }}
\end{aligned}
$$


Where:

$i$ denotes the individual commercial banks $(\mathrm{i}=1,2,3 \ldots . .28)$, $t$ denotes the yearly period ( $\mathrm{t}=1,2,3 \ldots .8), \alpha, \beta$ and $\beta$ denotes the coefficient to be estimated $\varepsilon$ is the residual terms

\section{RESULTS}

The results of the main specification in the present study are based on the four main determinants of engaging in OBS activities (i.e. liquidity motive, risk transfer motive, profitability motive and capital arbitrage motive). Four major econometric estimations are reported but the final result relies on the GMM estimation. The presence of the lagged independent variable in the GMM allows for the control of heterogeneity and autocorrelation in the estimation. This together with other qualities showed that the GMM is preferable as compared to other estimators.

The correlation coefficient was first carried out to ascertain the existence of multicollinearity. As indicated in Table 4, there is no issue of multicollinearity among the independent variables.

Table 4: Correlation Among the Variables

\begin{tabular}{|l|r|r|r|r|r|r|r|r|r|}
\hline & Ln OBS & LN TA & ed Loans/To Income sets / Tot LI Capital R & ROAA & GDP & Ln Loan \\
\hline Ln OBS & 1 & & & & & & & & \\
\hline LN TA & 0.589235 & 1 & & & & & & & \\
\hline Impaired & 0.146606 & 0.17427 & 1 & & & & & & \\
\hline Cost To In & 0.016822 & -0.21101 & 0.1204 & 1 & & & & & \\
\hline Liquid Ass & -0.50371 & -0.58803 & -0.25807 & 0.227945 & 1 & & & & \\
\hline Total Capi & -0.44917 & -0.48224 & -0.21891 & 0.112854 & 0.669171 & 1 & & & \\
\hline ROAA & 0.171028 & 0.275931 & -0.07978 & -0.26088 & -0.14252 & -0.10458 & 1 & & \\
\hline GDP & 0.10239 & 0.113961 & -0.16674 & 0.13833 & -0.05687 & -0.09215 & 0.014585 & 1 & \\
\hline Ln Loan & 0.841437 & 0.701324 & 0.204162 & -0.09392 & -0.75786 & -0.51069 & 0.171196 & 0.109335 & 1 \\
\hline
\end{tabular}

Based on the standard classification by Bankscope, OBS activities comprise of securitization related activities and contingent related activities. Our main focus was on contingent related activities that consist of guarantee, 
banker's acceptance and documentary credit reported off-balance sheet, committed credit line and other contingent liabilities. We opted for contingent related activities due to the fact that it constitutes the largest proportion of OBS activities by banks and data availability. Based on the information in Table 1, the total amount of commitment and contingencies related transaction by commercial banks increased from about RM1.8 billion to about RM2.5 billion between 2012 and 2016 which represents a 39 percent growth rate.

\section{Regression Result}

Table 5 below presents the results of the regression. The coefficient for size represented by the natural log of assets is negatively related in all the models. The negative relation is significant for both difference and system GMM. This suggests that larger banks may have less incentives to engage in OBS activities. Since large banks are sufficiently well diversified, they are more likely to have less incentive to use OBS instruments. Conversely, smaller banks are less diversified and have a high tendency to engage in OBS activities to manage their risks. This is in line with the finding of Khasawneh (2007), Khasawneh and Hassan (2010), Nachane and Ghosh (2002).

As indicated in Table 5, the ratio of impaired loan to equity representing the quality of assets of the bank is negatively related to OBS activities in almost all the models particularly in both difference and system GMM. This suggests that the usage of OBS instruments by the selected banks in Malaysia is not mainly for the risk transfer motive. This conceivably is attributed to the shift away from the self-regulatory and laissez-faire approach to a more stringent and corporate accountability system. This may prevent banks from taking undue advantage of OBS activities to be involved in highly risky transactions. Hence, the motive of taking excess risks with the aim of risk transfer is not the case in Malaysia. This result is contrary to that of Elian (2012) and Broccardo et al. (2014) who found a positive relationship for the case of the GCC and the Italian banking sector. This is not surprising as the Malaysian's banks maintain a high quality loan portfolio following the painful transition period of the 1997 Asian financial crisis (Moody, 2017). The Cost-to-income ratio variable and the ROA which represent profitability have a positive and negative relationship respectively with the OBS. 
The positive relationship between the cost-to-income ratio and the OBS activities could be inferred to suggest that banks use OBS activities to enhance the efficiency of their operation income. Similarly, the negative relationship between the ROA and the OBS suggests that banks tend to diversify to OBS activities to augment their operation profit. This is in line with Elian (2012) who revealed a similar result for the case of the GCC. The positive sign for the ratio of Liquid Assets-to-total deposit \& Borrowing suggests that the liquidity purpose is not a major motive for OBS activities in banks. This corroborates the Report of Moody's global credit research (2017) which indicated that the stable capital and liquid profile of Malaysian banks serves as buffer against continued weak operating conditions of the banking sector. The total capital ratio representing the regulatory capital requirement is significantly negatively related to the OBS in all the models. This suggests that banks with a less capital ratio are more likely to engage in OBS activities. The banks with a less capital ratio might use the OBS activities for the purpose of under-estimating their balance sheet risks to reduce their regulatory capital requirements. The loan variable is significantly positively related to OBS activities. This shows that loans generation and OBS are not substitutes. Thus it can be interpreted that banks possibly engage in OBS activities to mitigate the inherent risks of maturity mismatches resulting from loan transactions. As expected, the variable representing the macroeconomic factor is negatively related to the OBS activities. This suggests that banks tend to increase their OBS activities during an economic downturn to augment their operation profit.

Table 5: Regression Estimates

\begin{tabular}{|c|c|c|c|c|c|c|}
\hline & OLS & RE & FE & $\begin{array}{c}\text { Difference } \\
\text { GMM }\end{array}$ & $\begin{array}{l}\text { SYSTEM } \\
\text { GMM }\end{array}$ & $\begin{array}{l}\text { Robustness } \\
\text { System GMM }\end{array}$ \\
\hline Constant & $\begin{array}{c}-1.800905 \\
(0.013)\end{array}$ & $\begin{array}{c}-.0585878 \\
(0.945)\end{array}$ & $\begin{array}{c}.8799672 \\
(0.376)\end{array}$ & $\begin{array}{c}2.475422 \\
(0.001)\end{array}$ & 3.500572 & $3.500572(0.524)$ \\
\hline LnOBS & & & & $\begin{array}{c}-.0308267 \\
(0.008) \\
\end{array}$ & $\begin{array}{c}.0323947 \\
(0.008) \\
\end{array}$ & $.0323947(0.931)$ \\
\hline LnTA & $\begin{array}{c}.0048112 \\
(0.943)\end{array}$ & $\begin{array}{c}-.097275 \\
(0.167)\end{array}$ & $\begin{array}{c}-.1472773 \\
(0.073)\end{array}$ & $\begin{array}{c}-.1856539 \\
(0.006)\end{array}$ & $\begin{array}{c}-.3689969 \\
(0.000)\end{array}$ & $\begin{array}{c}-.3689969 \\
(0.339)\end{array}$ \\
\hline $\begin{array}{c}\text { Impaired } \\
\text { Loans / Equity }\end{array}$ & $\begin{array}{c}-.000856 \\
(0.755)\end{array}$ & $\begin{array}{c}-.0006798 \\
(0.797)\end{array}$ & $\begin{array}{c}.0001759 \\
(0.952)\end{array}$ & $\begin{array}{c}-.0015719 \\
(0.094\end{array}$ & $\begin{array}{c}-.0023677 \\
(0.012)\end{array}$ & $\begin{array}{c}-.0023677 \\
(0.728)\end{array}$ \\
\hline $\begin{array}{c}\text { Cost To } \\
\text { Income Ratio }\end{array}$ & $\begin{array}{c}.0076914 \\
(0.111)\end{array}$ & $\begin{array}{c}.0056025 \\
(0.326)\end{array}$ & $\begin{array}{c}.0032108 \\
(0.647)\end{array}$ & $\begin{array}{c}.0058578 \\
(0.028)\end{array}$ & $\begin{array}{c}.004584 \\
(0.002) \\
\end{array}$ & $.004584(0.754)$ \\
\hline $\begin{array}{l}\text { Liquid Assets / } \\
\text { Tot Dep\&Bor }\end{array}$ & $\begin{array}{c}.0303414 \\
(0.000)\end{array}$ & $\begin{array}{c}.0201595 \\
(0.000)\end{array}$ & $\begin{array}{c}.0126393 \\
(0.023)\end{array}$ & $\begin{array}{c}.0073996 \\
(0.007)\end{array}$ & $\begin{array}{c}.0115427 \\
(0.000)\end{array}$ & $.0115427(0.400)$ \\
\hline
\end{tabular}




\begin{tabular}{|c|c|c|c|c|c|c|}
\hline $\begin{array}{c}\text { Total Capital } \\
\text { Ratio }\end{array}$ & $\begin{array}{c}-.0163842 \\
(0.000)\end{array}$ & $\begin{array}{c}-.0136335 \\
(0.001)\end{array}$ & $\begin{array}{c}-.0118748 \\
(0.013)\end{array}$ & $\begin{array}{c}-.013118 \\
(0.000)\end{array}$ & $\begin{array}{c}-.013815 \\
(0.000)\end{array}$ & $-.013815(0.017)$ \\
\hline ROAA & $\begin{array}{c}.0507847 \\
(0.220)\end{array}$ & $\begin{array}{c}.0075891 \\
(0.850)\end{array}$ & $\begin{array}{c}-.0165439 \\
(0.694)\end{array}$ & $\begin{array}{c}-.009143 \\
(0.000)\end{array}$ & $\begin{array}{c}.010373 \\
(0.004)\end{array}$ & $-.010373(0.898)$ \\
\hline GDP & $\begin{array}{c}-.0132888 \\
(0.588)\end{array}$ & $\begin{array}{c}-.0061302 \\
(0.769)\end{array}$ & $\begin{array}{c}-.0019412 \\
(0.926)\end{array}$ & $\begin{array}{c}-.0003538 \\
(0.939)\end{array}$ & $\begin{array}{c}-.007796 \\
(0.225)\end{array}$ & $-.007796(0.745)$ \\
\hline LnLoans & $\begin{array}{c}1.009418 \\
(0.000)\end{array}$ & $\begin{array}{c}.9788582 \\
(0.000)\end{array}$ & $\begin{array}{c}.9692353 \\
(0.000)\end{array}$ & $\begin{array}{c}.8868682 \\
(0.000)\end{array}$ & $\begin{array}{c}.9094829 \\
(0.000)\end{array}$ & $.9094829(0.063)$ \\
\hline \multicolumn{7}{|l|}{ Sargan Test: } \\
\hline P-Value & & & & 0.3470 & 0.6703 & \\
\hline $\begin{array}{l}\text { AR (1): } \\
\text { p-Value }\end{array}$ & & & & 0.3099 & 0.2772 & \\
\hline $\begin{array}{l}\text { AR (1): } \\
\text { p-Value }\end{array}$ & & & & 0.4193 & 0.3780 & \\
\hline
\end{tabular}

\section{CONCLUSION}

This study provided empirical evidence on the motives behind the application of OBS instruments by some selected banks in Malaysia. The findings suggest that OBS instruments do not serves as incentives for the selected banks to imprudently accumulate risks on their balance sheets. As such, its usage poses no serious threat to the banking system. The findings further suggest that OBS instruments are employed to enhance efficiency, diversification purposes and to reduce regulatory capital requirements among the selected banks. The empirical evidence that we gathered equally suggests that OBS instruments help to boost loan generation for the banks. Based on the findings of the present study, the need for a sustainable stringent regulation is necessary for the long-term stability of the Malaysian financial system. This would help to ensure that, banks use opportunities offered by the OBS to prudently generate loans that pose no threat to the long term stability of the banks.

The limitation of the present study is that, it mainly focused on Malaysian banks. Further insights can be obtained when extending the studies to include other countries in the region. The comparison from the findings would shed more light on its usage and implications. 


\section{REFERENCES}

Affinito, M. \& Tagliaferri, E. (2010). Why do Banks Securitize their Loans? Evidence from Italy (Working Paper No. 741). Retrieved from http:// www.bancaditalia.it/pubblicazioni/temi-discussione/2010/2010 -0741/ en_tema_741.pdf

Ali Nasserinia A., Ariff M. \& Fan-Fah C. (2014). Key determinants of Japanese commercial banks performance. Pertanika Journal of Social Science and Humanities, 22, 17-38.

Arisyi, R., Agusman, A., Gasbarro, D., \& Monroe, G. S. (2015, August). Off-balance sheet derivatives and banking risk: Indonesian evidence. Paper presented at the 28th Australasian Finance and Banking Conference. Retrieved from https://ssrn.com/abstract $=2647435$

Bank Negara Malaysia. (2011). Financial Sector Blueprint (FSB) 20112020. Retrieved from http://www.bnm.gov.my/files/publication/fsbp/ en/BNM_FSBP_FULL_en.pdf

Bank Negara Malaysia. (2016). Financial Stability and Payment Systems Report 2016. http://www.bnm.gov.my/files/publication/fsps/en/2016 / zcp07_table_A.07.pdf

Bannier, C. E., \& Haensel D. (2007). Determinants of banks' engagement in loan securitization (Working Paper No. 85). Retrieved from https://dnb.info/990178641/34

Brewer, E. III, Jacson III, W. E. \& Moser, J.T. (1996). Alligators in the swamp: The impact of derivatives on the financial performance of depository institutions. Journal of Money, Credit, and Banking, 28(3), 482-497.

Broccardo, E., Mazzuca, M., \& Yaldiz, E. (2014). The use and determinants of credit derivatives in Italian banks. The Journal of Risk Finance, 15(4), 417-436. 
Cabiles, N. A. S. (2011). Hedging Illiquidity Risk through Securitization: Evidence from Loan Commitments. Proceedings of the Annual Meeting of the Midwest Finance Association, Chicago.

Calmes C. \& Liu, Y. (2009). Financial structure change and banking income: A Canada - US comparison. Journal of International Financial Market, Institutions and Money, 19(1), 128-139.

Calmes, C. \& Theoret, R. (2009). The impact of off-balance sheet activities on bank returns: An application of the ARCH-M to Canadian data. Journal of Banking \& Finance, 34, 1719-1728.

Calomiris, C. \& Mason, J. (2004). Credit Card Securitization and Regulatory Arbitrage. Journal of Financial Services Research, 26(1), 5-27.

Cardone-Riportella, C., Samaniego-Medina, R., \& Trujillo-Ponce, A. (2010) What drives bank securitization? The Spanish experience. Journal of Banking \& Finance, 34(11), 2639-2651.

Cerrato, M., Choudhry, M., Crosby, J., \& Olukuru, J. (2012). Why do UK banks securitize? (Working Paper). Available at http://ssrn.com/ abtract $=2051379$

Cooper, E. W. (2011). Determinants of off-balance sheet usage in private banks. Studies in Economics and Finance, 28(4), 248-259.

DeYoung, R., Lang, W., \& Nolle, D. (2007). How the internet affects output and performance at community banks. Journal of Banking and Finance 31, 1033-1060.

Drukker, D. M., Egger, P., \& Prucha, I. R. (2013). On two-step estimation of a spatial autoregressive model with autoregressive disturbances and endogenous regressors. Econometric Reviews, 32(5-6), 686-733.

Elian, M. (2012). Determinants of off-balance sheet business in the case of GCC banking sectors. International Journal of Banking and Finance, 9(3), 46-68. 
Goddard, J., Molyneux, P. \& Wilson, J. O. S. (2004). The profitability of European banks: A cross-sectional and dynamic panel analysis. The Manchester School, 72(3), 363-381.

Haq, M., \& Heaney, R. (2012). Factors determining European bank risk. Journal of International Financial Markets, Institutions and Money, 22(4), 696-718.

Hassan, M. K. \& Khasawneh, A. (2009). The risks of off-balance sheet derivatives in U.S. commercial banks' (Networks Financial Institute Working Paper 2009-WP-11). Retrieved from http://ssrn.com/ abstract $=1488264$

Hassan, M. K. (1992). The market perception of the riskiness of large U.S. bank commercial letters of credit. Journal of Financial Services Research, 6, 207-221.

Hochberg, Y., Sapienza, P., \& Vissing-Jorgensen, A. (2009). A lobbying approach to evaluating the Sarbanes-Oxley Act of 2002. Journal of Accounting Research 47, 519-583.

Ibrahim, M. H. \& Law, S. H. (2014). Social capital and CO2 emissionsoutput relations: A panel analysis. Renewable and Sustainable Energy Reviews, 29, 528-534.

Judson, R. A. \& Owen, A. L. (1996). Estimating dynamic panel data models: A guide for macroeconomics. Economics Letters, 65, 9-15.

Karim, M. Z. \& Gee. C. S. (2007). Off-balance sheet activities and performance of commercial banks in Malaysia. ICFAI Journal of Financial Economics, 5(4), 67-80.

Kashian R. D. \& Tao, R. (2014). Off-balance sheet activities and community bank performance. Journal of Economic Studies, 41(6), 789-807.

Khasawneh A. Y. \& Al-Khadash, H. A. (2014). Risk and profitability in Middle East and North Africa banking system: An examination of off balance sheet activities. The International Journal of Business and Finance Research, 8(3), 13-26. 
Lynge, M., \& Lee, C. F. (1987). Total risk, systematic risk, and off-Balance sheet risk for large commercial banks (Working paper No. 1398). University of Illinois at Urbana-Champaign. Retrieved from https:// core.ac.uk/download/pdf/4837011.pdf

Moody's Investors Service. (2017). Malaysian banks' 2016 results show weaker asset quality and profitability, resilient capital and liquidity. Retrieved from https://www.moodys.com/res earch/Moodys-Malaysianbanks-2016-results-show-weaker-asset-quality-and--PR_362893

Nachane, D. M. \& Saibal, G. (2007). An empirical analysis of the offbalance sheet activities of Indian banks (MPRA Paper No. 17304). Retrieved from Munich Personal RePEc Archive website: http://mpra. ub.unimuenchen.de/17304/

Pereraa, A., Ralstona D., \& Wickramanayakea, J. (2014). Impact of off-balance sheet banking on the bank lending channel of monetary transmission: Evidence from South Asia. Journal of International Financial Markets, Institutions and Money, 29, 195-216.

Shyu, Y. W. \& Reichert, A. K. (2015). The determinants of derivative use by U.S. and foreign banks. Research in Finance, 19, 143-172.

Xiaohui H, Wang Q, \& Li, C. (2015). Role of off-balance sheet operations on bank scale economies: Evidence from China's banking sector. Emerging Markets Review 22, 140-153.

Yiwei, D. \& Xu, Z. (2017). Off-balance-sheet securitization, bank lending, and firm innovation. UNSW Business School finance seminar and the NYU Stern accounting brown-bag seminar. Retrieved from http://www. law.northwestern.edu/research-faculty/searlecenter/e vents/innovation/ documents/xu_obs_lending_innovation.pdf

Ziadeh-Mikati N. (2014). Bank risk exposure, bank failure and off balance sheet activities: An empirical analysis for U.S. commercial banks. https://economix.fr/fr/recrutement/2014/jpo-2014/papier_Ziadeh.pdf 